\title{
Characterization of a unique protein component of yeast RNase MRP: an RNA-binding protein with a zinc-cluster domain
}

\author{
Mark E. Schmitt ${ }^{1}$ and David A. Clayton ${ }^{2}$ \\ Department of Developmental Biology, Stanford University School of Medicine, Stanford, California 94305-5427 USA
}

\begin{abstract}
RNase MRP is a ribonucleoprotein endoribonuclease that has been shown to cleave mitochondrial primer RNA sequences from a variety of sources. Most of the RNase MRP activity is found in the nucleus where it plays a role in the processing of 5.8S rRNA. A temperature-conditional point mutation in the yeast RNA component of the enzyme has been identified. This mutation results in a loss of normal rRNA processing at the nonpermissive temperature while cellular levels of the RNA component of RNase MRP remain stable. High-copy suppressor analysis of this point mutation was employed to identify interacting proteins. A unique suppressor, termed SNM1 (suppressor of nuclear mitochondrial endoribonuclease 1), was identified repeatedly. The SNM1 gene was localized to the right arm of chromosome IV, directly adjacent to the SNF1 gene, and it contains an open reading frame encoding a protein of 198 amino acids. The protein contains a leucine zipper motif, a zinc-cluster motif, and a serine/lysine-rich tail. The gene was found to be essential for viability in a yeast cell, consistent with it being a protein component of the RNase MRP ribonucleoprotein complex.

Recombinant SNM1 protein binds RNA in both gel retardation and Northwestern assays. Antibodies raised against bacterially expressed proteins identified four separate species in yeast whole cell extracts. Antibodies directed against the SNM1 protein immunoprecipitated RNase MRP RNA from whole-cell extracts without precipitating the structurally and functionally related RNase P RNA. We propose that the SNM1 protein is an essential and specific component of the RNase MRP ribonucleoprotein complex, the first unique protein of this complex to be identified.
\end{abstract}

[Key Words: Endoribonuclease; RNA processing; RNase MRP; RNase P; Saccharomyces cerevisiae; yeast]

Received July 18, 1994; revised version accepted September 1, 1994.

Ribonucleoproteins (RNPs) have been implicated in a wide array of biological processes within the cell, which include established roles in rRNA processing (Tollervey 1987, Fournier and Maxwell 1993), mRNA splicing (Mattaj et al. 1993), mRNA translation (Noller and Woese 1981, Woolford 1991), functions relevant to synthesis of chromosomal telomeres (Greider and Blackburn 1989), processing of tRNAs (Bartkiewicz et al. 1989), and replication of organellar DNA (Wong and Clayton 1986). A novel mitochondrial RNA processing endoribonuclease (RNase MRP) that has the capacity to cleave mitochondrial RNA complementary to the light strand of the displacement loop at a unique site has been characterized from mouse cells (Chang and Clayton 1987a,b, 1989). This endonuclease has been implicated in the metabolism of RNA primers for the leading strand of mitochon-

\footnotetext{
${ }^{1}$ Present address: Department of Biochemistry and Molecular Biology, State University of New York Health Science Center at Syracuse, Syracuse, New York 13210 USA.

${ }^{2}$ Corresponding author.
}

drial DNA replication. The sensitivity of RNase MRP to ribonuclease or protease digestion demonstrated a requirement for both RNA and protein components for site-specific cleavage by this endonuclease /Chang and Clayton 1987b).

The gene encoding the RNA component of RNase MRP RNA (MRP RNA) has been isolated from several different vertebrates (Chang and Clayton 1989; Topper and Clayton 1990a; Bennett et al. 1992; Dairaghi and Clayton 1993/ and from Saccharomyces cerevisiae (Schmitt and Clayton 1992) and Schizosaccharomyces pombe (J. Paluh and D.A. Clayton, in prep.). The enzyme has been shown to cleave an RNA species complementary to mitochondrial origins in a variety of species and across distant evolutionary boundaries (Stohl and Clayton 1992).

Autoimmune antibodies to RNase MRP have been used to establish its antigenic relationship with RNase $P$ and identity with the Th/To RNP (Gold et al. 1989). Also, structural studies of MRP RNA using chemical modification of the RNA (Topper and Clayton 1990b) or 
phylogenetic comparison (Forster and Altman 1990; Schmitt et al. 1993) have revealed that MRP RNA is structurally and evolutionarily related to the RNA component of RNase $\mathrm{P}$, the ribonucleoprotein endoribonuclease that processes the $5^{\prime}$ ends of pre-tRNAs.

Cellular fractionation and immunolocalization have shown RNase MRP to be present in two distinct compartments, the mitochondria and the nucleus (Reimer et al. 1988; Chang and Clayton 1989; Gold et al. 1989; Karwan et al. 1991; Topper et al. 1992; Li et al. 1994). Some controversy had arisen from a report that little or no detectable MRP RNA can be found in mitochondria of animal and plant cells (Kiss et al. 1992; Kiss and Filipowicz 1992). This result is inconsistent with results published previously (Chang and Clayton 1989; Topper and Clayton 1990; Karwan et al. 1991; Topper et al. 1992) and a study published recently utilizing in situ electron microscopy and cell fractionation ( $\mathrm{Li}$ et al. 1994), and may simply reflect the low relative cellular amount of mitochondrial MRP RNA.

Using regulated expression and temperature-conditional mutations of $N M E 1$ (the gene encoding $S$. cerevisiae MRP RNA) a specific role for RNase MRP in processing 5.8S rRNA was identified (Schmitt and Clayton 1993). This rRNA processing event regulates the ratio of two different species of 5.8S rRNA (Rubin 1974). Translation in yeast depleted of the smaller 5.8S rRNA remains robust but does show a loss of translation of a subset of proteins, suggesting a possible role of the two $5.8 \mathrm{~S}$ rRNAs in regulating translation of select messages (Schmitt and Clayton 1993). In support of these findings, a yeast mutation displaying a similar defect to a nme1 mutant in rRNA processing (rrp2) (Shuai and Warner 1991; Lindahl et al. 1992) has now been shown to be in the NME1 gene (Chu et al. 1994).

Several mutations in the gene for yeast MRP RNA (NME1) have been isolated (Schmitt and Clayton 1993; M.E. Schmitt, G.S. Shadel, and D.A. Clayton, unpubl.). One of these mutations, nme1-P6, shows a tight temperature-sensitive growth phenotype and a strong defect in the processing of the $5.8 \mathrm{~S}$ rRNA at the nonpermissive temperature (Schmitt and Clayton 1993). Levels of MRP RNA in the nme1-P6 mutation have been found to remain stable even at the nonpermissive temperature, and this same $G \rightarrow A$ transition at position 122 of MRP RNA has been identified in mutant screens by three different groups (Shuai and Warner 1991; Schmitt and Clayton 1993; Chu et al. 1994).

Despite the fact that the gene for a mammalian MRP RNA was cloned and sequenced several years ago /Chang and Clayton 1989), only one of the protein components of the enzyme has been identified and its gene has not been isolated (Yuan et al. 1991). Other than this peptide, the exact protein composition of the complex remains unclear (Rossmanith and Karwan 1993). Any future work on biogenesis of the RNase MRP complex or transport of the complex and its RNA component throughout the cell will require defining the protein composition of the active complex and cloning of the genes for these proteins. In an effort to isolate protein components of the $S$. cerevisiae RNase MRP complex, we have employed a high-copy suppression scheme utilizing the nme1-P6 temperature-conditional mutation in the RNA component. We report here the cloning and characterization of a unique and essential protein component of the yeast RNase MRP enzyme.

\section{Results}

Isolation of a high-copy suppressor of the nmel-P6 mutant

A yeast genomic library in the yeast vector YEP24 (Carlson and Botstein 1982) was screened for genes capable of suppressing the nme1-P6 mutation when present in high copy (Rine 1991). Four separate isolates were found to confer plasmid-dependent suppression by allowing growth of the nme1-P6 mutant at $37^{\circ} \mathrm{C}$. Growth at $37^{\circ} \mathrm{C}$ of one of the suppressing strains is shown (Fig. 1). Its growth rate is less rapid than the wild-type strain but is still severalfold higher than the nme1-P6 mutation. All four of the high-copy suppressors were dependent on the plasmid carrying the nme1-P6 mutation, indicating that they were not the wild-type $N M E 1$ gene.

The four suppressor plasmids were mapped by restriction analysis and found to contain overlapping fragments of the same region of the yeast genome (Fig. 2A). The gene was named SNM1 for suppressor of NME1. Through the use of an ordered yeast genomic library (Riles et al. 1993) the inserts were mapped to the right arm of chromosome IV adjacent to the SNF1 gene (Celenza and Carlson 1984). The SNF1 gene encodes a protein kinase involved in the transcription regulation of multiple genes in response to glucose (Celenza and Carlson 1986). The restriction map of the SNF1 gene was found to be identical to that of our suppressors (Celenza and Carlson 1984). The entire SNF1 gene was within all of our overlapping inserts; however, a $3.2-\mathrm{kb}$ fragment that included the entire $S N F 1$ gene was unable to confer suppression on the nme1-P6 mutation. Further subcloning

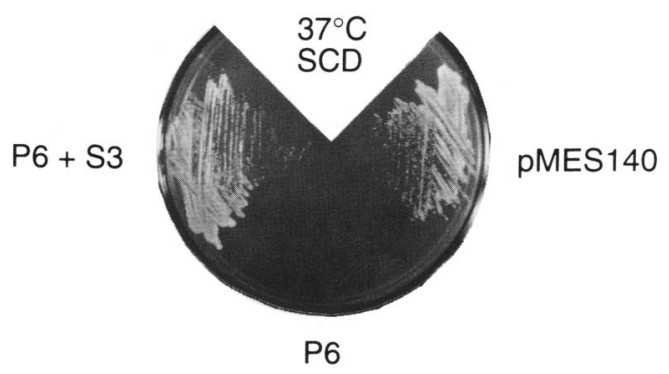

Figure 1. The S3 suppressor restores growth to yeast carrying the nme1-P6 mutation. Yeast strains were spread onto SCD plates at $37^{\circ} \mathrm{C}$ and grown for $24 \mathrm{hr}$ before photographing. (pMES140) Yeast strain carrying a wild-type NME1 gene on a LEU2/CEN plasmid; (P6) yeast strain carrying the nme1-P6 mutation on a $L E U 2 / C E N$ plasmid; $(\mathrm{P} 6+\mathrm{S} 3)$ yeast strain carrying the nme1-P6 mutation on a $L E U 2 / C E N$ plasmid and the suppressing $U R A 3 / 2 \mu$ plasmid, S3. 

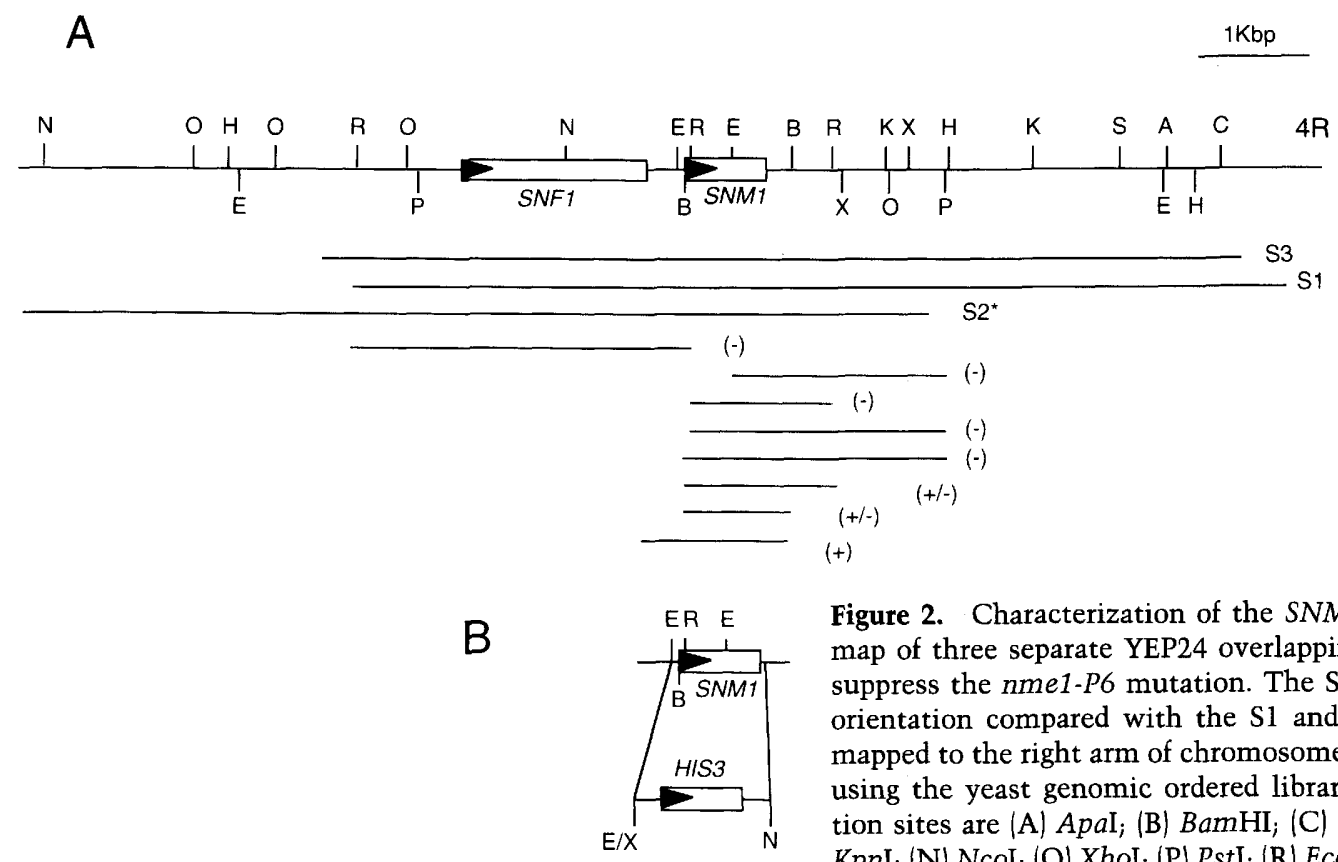
lines below the restriction map represent fragments of this region that were tested for suppression of the nme1-P6 mutation when in the yeast $2 \mu$ /URA3 vector YEP351. The ability of these subclones to suppress is indicated by a $|-|$, no suppression; $|+|-\mid$, suppression at intermediate temperatures; or (+1, suppression at $37^{\circ} \mathrm{C} .(B)$ A $1.2-\mathrm{kb}$ fragment of the SNM1 gene was deleted from the SpeI to the Nsil sites, and a 1305-bp NsiI-XbaI DNA fragment containing the entire HIS3 gene was inserted into it. This construct was used to delete the chromosomal copy of $S N M 1$ by integrative transformation and homologous recombination (Rothstein 1991; see Materials and methods).

and deletion analysis identified a $1.0-\mathrm{kb}$ fragment downstream of the SNF1 gene that conferred partial suppression of the nme1-P6 mutation, and an overlapping 1.2-kb fragment that conferred full suppression (Fig. 2A).

The SNM1 suppressor restores $r$ RNA processing in the nmel-P6 mutant without affecting the transcription or stability of the RNA

It might be expected that overexpression of the nme1-P6 gene could generate more RNase MRP enzyme, which might partially alleviate the defect. To ensure that the suppressors were not affecting expression, nme1-P6 RNA levels were examined by Northern analysis (Fig. 3A). Little change was observed when comparing wildtype NME1 levels to levels in the nme1-P6 mutant or the nme1-P6 mutant carrying the $\mathrm{S} 3$ suppressor plasmid (Fig. 2A). These results indicate that this suppression is not attributable to increased transcription of the NME1 gene.

The nme1-P6 mutation exhibits impaired translation of a select group of proteins at the nonpermissive temperature (Schmitt and Clayton 1993). It was postulated that at least one of these proteins might be essential for viability in yeast, which would explain why the NME1 gene is essential. Thus, a second way to bypass this mutation would be to overexpress the essential protein, thereby providing enough of this protein for the cells to survive. To test this hypothesis we examined the rRNA processing defect in the nme1-P6 mutation when it was carrying the minimal $1.2-\mathrm{kb}$ suppressing fragment on a high-copy plasmid, pMES202 (Fig. 3B). After $4 \mathrm{hr}$ at the nonpermissive temperature the nme1-P6 mutation has the characteristic shift in the ratio of the $5.8 \mathrm{~S}(\mathrm{~L})$ to $5.8 \mathrm{~S}$ (S) rRNA species [we use the terminology of $5.8 \mathrm{~S}(\mathrm{~L})$ for the 7-nucleotide longer species and $5.8 \mathrm{~S}(\mathrm{~S})$ for the shorter species, as suggested by Henry et al. 1994] reported for this mutant (Schmitt and Clayton 1993). When the nme1-P6 mutant is carrying the high-copy SNM1 gene, the processing of $5.8 \mathrm{~S}$ rRNA is restored to near normal. This suggests that the SNM1 gene is working directly at the level of the RNase MRP enzyme, rather than bypassing the translation defect by supplying an essential protein that was depleted.

The SNM1 gene encodes a $22-k D$ protein with a novel zinc-cluster domain

The nucleotide sequence from the $3^{\prime}$ end of the SNF1 gene to the downstream $X b a I$ site (see Fig. 2A) was determined. Two open reading frames were found. The first reading frame was oriented in the opposite direction of the SNF1 gene and extended past the $X b a I$ site. This open reading frame was not on the minimal suppressing fragment and showed no homology to any genes sequenced previously. The minimal suppressing fragment contained the second open reading frame that is predicted to encode a protein of 198 amino acids (Fig. 4) with a molecular mass of $22.5 \mathrm{kD}$. This protein showed no striking similarities to any known proteins. However, three interesting regions were found in the predicted se- 
A

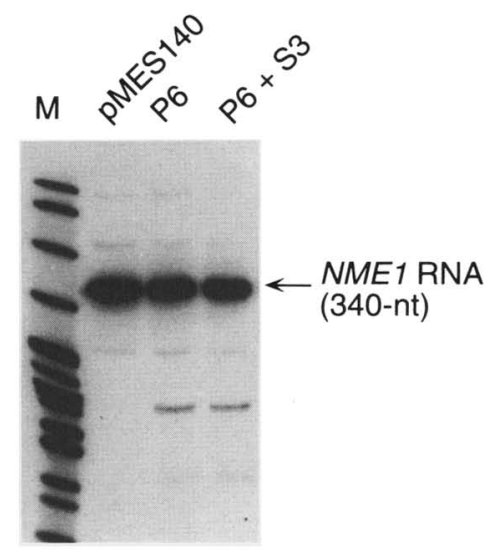

B

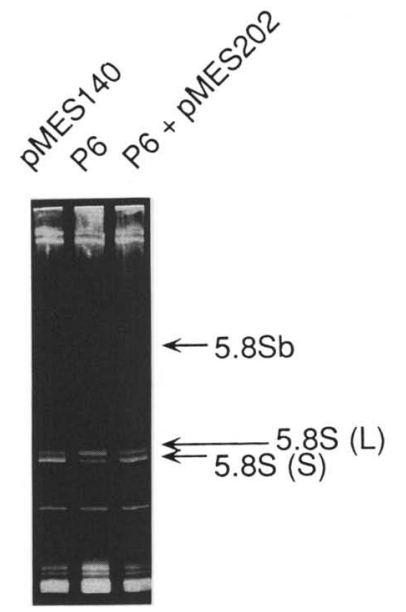

Figure 3. I Ine SIVIVI 1 gene restores IKIVA processing but has no effect on the stability or synthesis of MRP RNA in the nme1-P6 mutant. Yeast strains were grown to $2 \times 10^{7}$ cells $/ \mathrm{ml}$ at $24^{\circ} \mathrm{C}$ on YPD and then shifted to $37^{\circ} \mathrm{C}$ for $4 \mathrm{hr}$. The cells were then collected, and total RNA was isolated. $(A)$ Equal amounts of total RNA were separated on a $6 \%$ acrylamide $/ 7 \mathrm{M}$ urea gel, transferred to nylon, and probed with the NME1 gene. $(B)$ Equal amounts of total RNA were separated on a $6 \%$ acrylamide $/ 7 \mathrm{M}$ urea gel and stained with ethidium bromide. The locations of the relevant $5.8 \mathrm{~S}(\mathrm{~S}), 5.8 \mathrm{~S}(\mathrm{~L})$, and $5.8 \mathrm{Sb}$ are shown (Schmitt and Clayton 1993). (pMES140) Yeast strain carrying a wild-type NME1 gene on a LEU2/CEN plasmid; (P6) yeast strain carrying the nme1-P6 mutation on a $L E U 2 / C E N$ plasmid; (P6+S3) yeast strain carrying the nme1-P6 mutation on a $L E U 2 / C E N$ plasmid and the suppressing $U R A 3 / 2 \mu$ plasmid S3; (P6+ pMES202) yeast strain carrying the nme1-P6 mutation on a $L E U 2 / C E N$ plasmid and the minimal $1.2-\mathrm{kb}$ suppressing fragment on a $U R A 3 / 2 \mu$ plasmid, pMES202. Size markers are ${ }^{32}$-labeled HpaII-digested pBR322.

quence. The amino-terminal 35 amino acids of the protein contained a series of leucines spaced 6-8 amino acids apart that could potentially form a leucine-zipper dimerization domain similar to the GAL4 protein (Busch and Sassone-Corsi 1990; Marmorstein et al. 1992). The central part of the protein (amino acids 61-109) contains two cysteine clusters. Similar cysteine clusters have been shown to bind two zinc ions in a binuclear cluster arrangement (O'Halloran 1993). The best-described example of such a zinc cluster is again found in the GAL4 protein (Marmorstein et al. 1992). Evidence from the purification of the recombinant protein from Escherichia coli suggests that the SNM1 protein binds zinc (see Materials and methods|. The carboxy-terminal part of the protein (amino acids 136-198) is rich in serines and lysines. In the last 63 amino acids, 15 are serines and 16 are lysines. This region is similar to the arginine/serinerich domain (RS) found in many RNA-binding proteins involved in splicing (Birney et al. 1993).

\section{The SNM1 gene is essential for viability in yeast}

The entire coding region of the SNM1 gene was deleted by insertional replacement with the HIS3 gene (Fig. 2B). The deletion removes the region from the SpeI site at position -60 to the $N$ siI site $88 \mathrm{bp}$ after the termination codon (Fig. 4). This deletion was confirmed in yeast by using polymerase chain reaction (PCR) and Southern analysis (data not shown). The deleted diploid strain MES150 was sporulated, and 20 tetrads were dissected; all gave a 2:0 segregation for viability. The two inviable spores were examined under the microscope and found

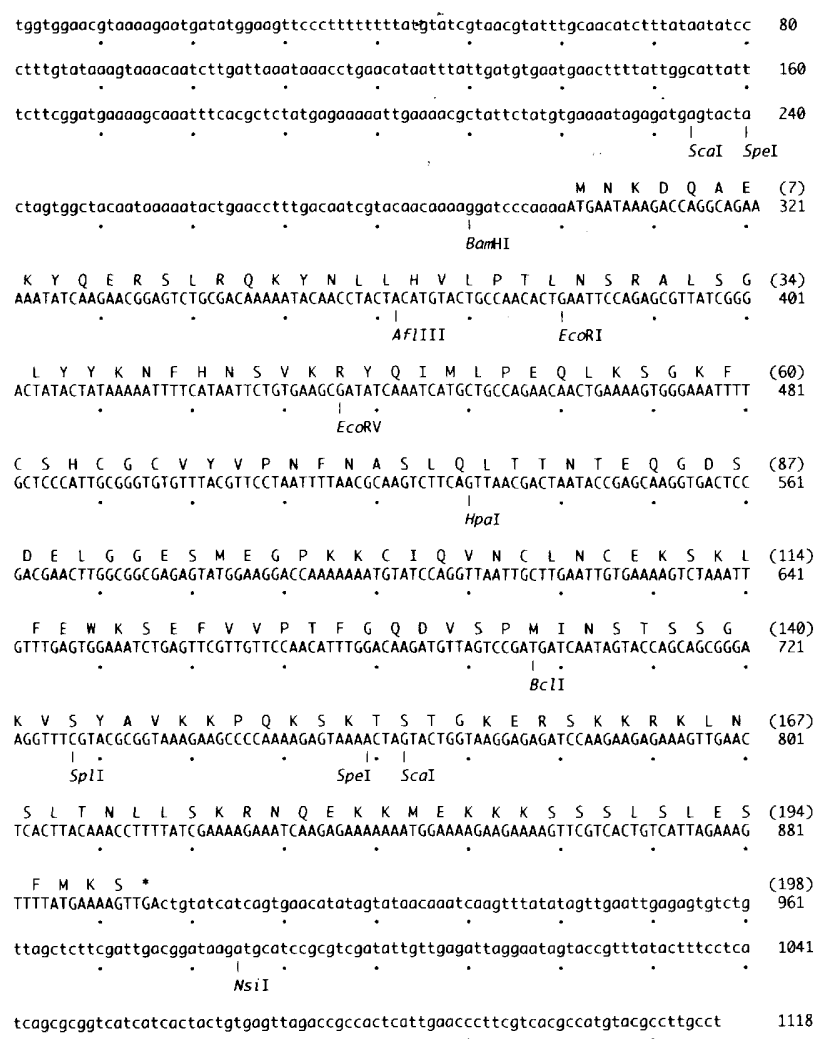

Figure 4. DNA and predicted protein sequence of the minimal suppressing fragment. The sequence shown starts 1 bp 3' of the SNF1 termination codon (Celenza and Carlson 1986). A second long open reading frame running in the opposite direction ends $\sim 250$ bp downstream of the SNM1-protein-coding region; this sequence has been deposited with the rest of the SNM1 sequence (EMBL accession no. Z37982). 
to be at either the one- or two-cell stage. All viable spores required histidine for growth, indicating that spores receiving the HIS3 marker were inviable and that the SNM1 gene is essential for viability in yeast.

To ensure that the gene was not simply required for germination of spores, the MES150 strain was transformed with either a yeast $2 \mu$ plasmid (pMES202) or a CEN plasmid (pMES194) containing the SNM1 gene. The resultant strains were sporulated, and tetrads were dissected. His ${ }^{+}$spores were identified at an expected frequency, although these strains were always $\mathrm{Leu}^{+}$or $\mathrm{Ura}^{+}$, indicating that they maintained the pMES194 or pMES202 plasmids, respectively. These plasmids were not lost from haploid $s n m 1^{-}$-deleted cells, confirming that the SNM1 gene is required for viability.

\section{High-copy maintenance of the SNM1 gene results in exceptionally high levels of transcription of the SNM1 gene}

The SNM1 transcript was examined by Northern analysis in a wild-type strain, in a strain with the nme1-P6 mutation, and in a strain with the nme1-P6 mutation carrying the $S N M 1$ gene on a high-copy plasmid. As shown in Figure 5A, the SNM1 gene encodes a transcript of 800 nucleotides. This is the expected size for a yeast gene with an open reading frame of $594 \mathrm{bp}$. Closer examination of the signal in the wild-type (pMES140) case reveals a second transcript 50-75 nucleotides larger. The nme1-P6 mutation carrying the SNM1 suppressor exhibited a $>50$-fold overexpression of the SNM1 transcript, a level consistent for a yeast gene placed onto a high-copy plasmid (Rine 1991).

\section{High SNM1 transcript levels give a moderate increase in protein levels and the SNM1 protein appears to be modified}

The SNM1 protein was expressed in E. coli using a pT7-7 expression system and purified to near homogeneity (>95\%). Rabbit polyclonal antibodies were generated against the bacterially expressed SNM1 protein and used to analyze the protein in yeast. The $S N M 1$ protein was examined by Western analysis in a wild-type strain, in a strain carrying the nme1-P6 mutation, and in a strain with the nme1-P6 mutation carrying the SNM1 gene on a high-copy plasmid. Whole-cell protein extracts were separated on a $15 \%$ polyacrylamide gel, transferred to nitrocellulose, and probed with antibodies directed against the SNM1 protein (SNM1-p). The anti-SNM1-p antibodies were initially cleared against an $E$. coli lysate to remove nonspecific antibodies and then used at a 1: 1500 dilution. At this dilution the antibodies are expected to be highly specific. The antibodies react with four separate protein species in the wild type (pMES140) lane (Fig. 5B). These protein species migrate considerably slower than expected for a molecular mass of $22.5 \mathrm{kD}$, as predicted from the gene sequence. However, the recombinant protein migrates at the exact same mobility as the fastest migrating species in Figure 5B (data not shown).
A

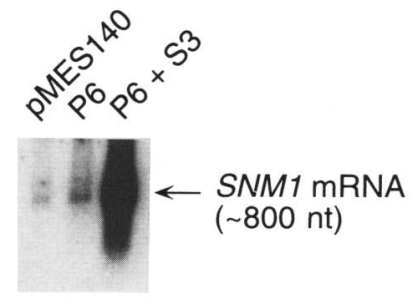

B

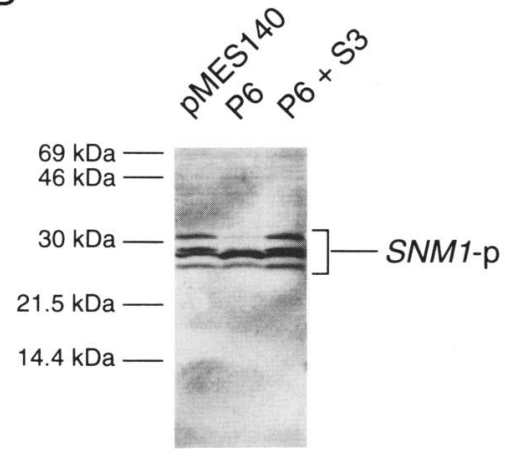

Figure 5. Transcriptional and translational analysis of the SNM1 gene. Yeast strains were grown to $2 \times 10^{7}$ cells $/ \mathrm{ml}$ at $24^{\circ} \mathrm{C}$ on YPD and then shifted to $37^{\circ} \mathrm{C}$ for $4 \mathrm{hr}$. The cells were then collected and total RNA was purified from one-half of the population and whole-cell protein extracts were made from the other half. $(A)$ Ten micrograms of total RNA from the strains indicated were separated by electrophoresis on a $1 \%$ formaldehyde-agarose gel and blotted to nylon. The mRNA corresponding to transcripts from the SNM1 allele was visualized by hybridization with a ${ }^{32} \mathrm{P}$-labeled probe corresponding to the $521-\mathrm{bp}$ ACCI fragment containing the SNM1 coding region. Location of the SNM1 transcript is indicated. $(B)$ Fifty micrograms of protein from each yeast strain was denatured in $2 \%$ SDS and $5 \%$ 2 -mercaptoethanol for $5 \mathrm{~min}$ at $95^{\circ} \mathrm{C}$. SDS-PAGE was then performed through a $15 \%$ polyacrylamide gel, and the protein was subsequently transferred to nitrocellulose and probed with a rabbit polyclonal anti-SNM1-p antibody at a 1:1500 dilution. The blot was then probed with a secondary peroxidase-antirabbit antibody and visualized with the Amersham ECL chemiluminescence kit. (pMES140) Yeast strain carrying a wild-type NME1 gene on a LEU2/CEN plasmid; (P6) yeast strain carrying the nme1-P6 mutation on a $L E U 2 / C E N$ plasmid; $(\mathrm{P} 6+\mathrm{S} 3)$ yeast strain carrying the nme1-P6 mutation on a $L E U 2 / C E N$ plasmid and the suppressing $U R A 3 / 2 \mu$ plasmid S3.

The aberrant mobility may result from a high degree of charge in the SNM1 protein. Three slower mobility species were also found in whole-cell extracts, which probably represent modified forms of the SNM1 protein. In the nme1-P6 mutation (Fig. 5B, lane P6) a different SNM1 protein profile is seen. The two slowest mobility proteins became very low-abundance species, whereas an intermediate form became the major form. Several duplicate experiments revealed that the overall levels of the SNM1 protein never dropped below $50 \%$ of the level of the wild type in the nme1-P6 mutant. In the nme1-P6 mutant carrying the SNM1 high-copy suppressor, the protein profile essentially returns to that of the wild type with no more than a $50 \%$ increase in expression over 
wild-type protein levels. This is in contrast to the SNM1 transcript levels, which increase $>50$-fold relative to wild type.

\section{The SNM1 protein binds MRP RNA in vitro}

The SNM1 protein might suppress the nme1-P6 mutation by interacting directly with the enzyme complex as

A

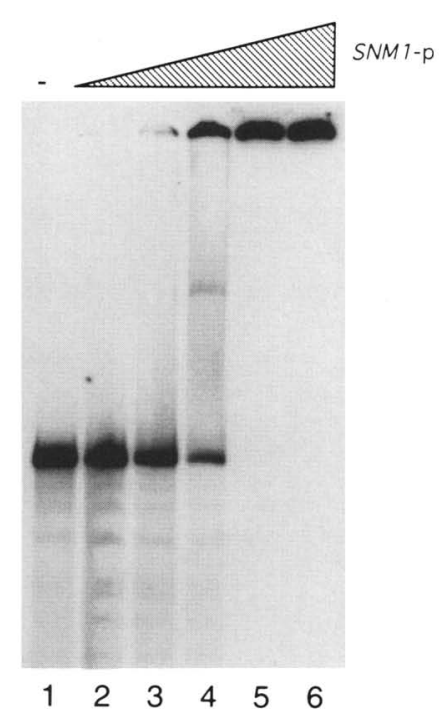

B

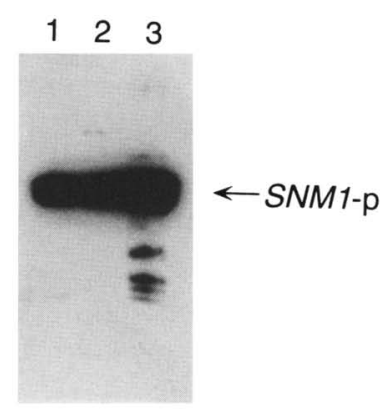

Figure 6. Purified SNM1-p binds MRP RNA in vitro. SNM1-p was purified from $E$. coli as described in Materials and methods. (A) Increasing amounts of the purified SNM1-p (lane 1) 0 pmole of SNM1-p; (lane 2) 0.15 pmole of SNM1-p; (lane 3) 0.25 pmole of SNM1-p; (lane 4) 0.5 pmole of SNM1-p; (lane 5) 1 pmole of SNM1-p; (lane 6) 2 pmoles of SNM1-p were incubated with 0.5 pmole of $\left[{ }^{32} \mathrm{P}\right] \mathrm{pCp}$-labeled MRP RNA in $0.5 \times$ TBE for $20 \mathrm{~min}$. The samples were then loaded on a $4 \%$ acrylamide, $0.5 \times$ TBE gel, and the RNA-protein complexes were separated by electrophoresis. The gel was dried and subjected to autoradiography. (B) Increasing amounts of the SNM1-p [(lane 1) $75 \mathrm{ng}$; (lane 2) $150 \mathrm{ng}$, (lane 3) $300 \mathrm{ng}$ ) were separated on a $15 \%$ SDS-poylacrylamide gel and transferred to nitrocellulose. The blot was blocked with $5 \%$ BSA, $0.1 \%$ Triton X-100 in PBS for $1 \mathrm{hr}$ and incubated in PBS with $0.1 \%$ Triton X-100, $1 \mu \mathrm{g} / \mathrm{ml}$ of $E$. coli tRNA and $2 \times 10^{6} \mathrm{cpm}$ of internally ${ }^{32} \mathrm{P}$-labeled MRP RNA at $10^{9}$ $\mathrm{cpm} / \mu \mathrm{g}$ for $30 \mathrm{~min}$ at $24^{\circ} \mathrm{C}$. The blot was then washed $4 \times 10$ min in PBS with $0.1 \%$ Triton X-100 at $24^{\circ} \mathrm{C}$ and exposed to film. The location of the full-length SNM1-p is indicated. a protein component. To determine whether the SNM1 protein binds MRP RNA, we attempted to gel shift in vitro-transcribed NME1-derived MRP RNA by adding purified recombinant SNM1 protein (Fig. 6A). The SNM1 protein was purified to near homogeneity from bacteria. By use of Coomassie blue staining intensity it is estimated that the protein is $\sim 95 \%$ pure. This protein was used for both antibody production (Fig. 5B) and for in vitro RNA-binding experiments.

When purified SNM1 protein was incubated with MRP RNA, a dramatic shift in the mobility of the free MRP RNA on a native polyacrylamide gel was seen (Fig. 6A). The shifted RNA barely enters a $4 \%$ polyacrylamide gel, indicating the large size of the RNA-protein complex. The binding appears to be highly cooperative and occurs at a 1:1 molar ratio of RNA to protein (Fig. 6A, lane 4). At the ratio of $1: 1, \mathrm{RNA} /$ protein, a intermediate species was observed that may represent a complex of one protein and one RNA molecule. Complex formation could be inhibited by $E$. coli tRNA but only when competitor tRNA was present at concentrations $>100 \mu \mathrm{g} / \mathrm{ml}$, indicating that the protein has a high degree of specificity for the MRP RNA (data not shown).

Purified SNM1 protein was also found to bind MRP RNA in a Northwestern experiment (see Fig. 6B). Immobilized SNM1 protein was able to bind MRP RNA in solution at picomolar concentrations. Again, competing tRNA was unable to prevent complex formation when present in concentrations up to $100 \mu \mathrm{g} / \mathrm{ml}$ /data not shown; this translates into a tRNA/MRP RNA ratio of nearly $350,000: 1$ ).

\section{The SNMI protein is a component of the RNase MRP complex}

To test whether the SNM1 protein actually binds MRP RNA in vivo, we utilized a coimmunoprecipitation experiment. A yeast whole-cell extract was incubated with the anti-SNM1-p antibody that had been attached to protein A-Sepharose. RNA that coimmunoprecipitated with the SNM1 protein was analyzed by Northern analysis (Fig. 7). A portion of the MRP RNA was found to immunoprecipitate with the anti-SNM1-p antibodies, yet neither SCR1 RNA (yeast signal recognition particle RNA) (Felici et al. 1989) nor nuclear RNase P RNA (Lee et al. 1991) were precipitated by these antibodies. Although the immunoprecipitation was specific, a majority of the MRP RNA remained in the supernatant under the conditions used here and in repeat experiments with this antibody. Thus, it remains to be determined whether all of the cellular MRP RNA is stably associated with antigenically accessible SNM1 protein or whether the enzyme physically exists in more than one ribonucleoprotein form. This result suggests that the SNM1 protein is an integral component of the RNase MRP enzyme complex. Also, it demonstrates that the SNM1 protein is different from the human $\mathrm{Th} / \mathrm{To}$ antibody antigen that can immunoprecipitate both the RNase MRP and RNase P RNAs from mouse and human cells (Gold et al. 19891 . 


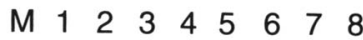

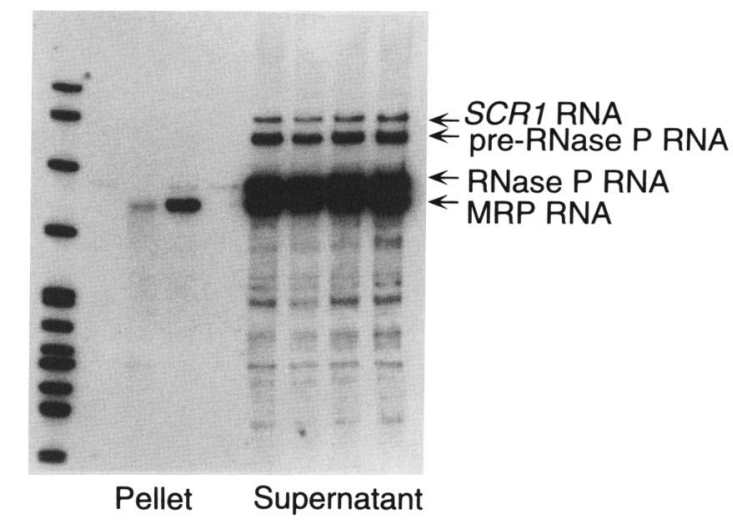

Figure 7. SNM1-p binds MRP RNA in vivo. Northern analysis showing RNAs that are immunoprecipitated with the polyclonal anti-SNM1-p antibodies. The Northern blot was screened with probes for MRP RNA, SCR1 RNA, and RNase P RNA. The locations of the hybridizing species are indicated. (Lanes 1-4) The pellets from the immunoprecipitations; (lanes 5-8) the corresponding supernatants. (Lanes 1,5) No antibody; (lanes 2,6) 1 $\mu \mathrm{l}$ of anti-SNM1-p serum; (lanes 3,7) $2 \mu \mathrm{l}$ of anti-SNM1-p serum; (lanes 4,8) $2 \mu \mathrm{l}$ of preimmune serum. Size markers are ${ }^{32} \mathrm{P}-\mathrm{la}$ beled HpaII-digested pBR322.

\section{Discussion}

The SNM1 protein is the first identified protein component unique to the RNase MRP enzyme complex

The SNM1 gene was identified in a screen for suppressors of a point mutation in the NME1 gene. We identified only one gene that suppresses the nme1-P6 mutation, despite the isolation of four separate suppressors; this suggests a specificity of the SNM1 gene for this mutation. We failed to isolate the wild-type NME1 gene in this screen; this may be because of a partial dominance of the nme1-P6 mutation. The evidence presented in this paper (which follows) shows that we have identified a protein, SNM1, that is an essential and specific component of the RNase MRP enzyme.

The SNM1 suppressor reverses the rRNA processing defect that occurs in the nme1-P6 mutation, indicating that it is working specifically on the RNase MRP complex instead of bypassing the function of the enzyme. This result suggests that the protein is a component of the RNase MRP enzyme complex. This also lends credence to the assumption that the 5.8S rRNA processing defect is causing the lethality seen in NME1 deletions in yeast (Schmitt and Clayton 1993).

Like the NME1 gene, the SNM1 gene was found to be essential for viability in yeast. This is the same phenotype that was observed for an NME1 deletion and is a consistent result for a gene that encodes an essential protein component of the RNase MRP enzyme. Mutagenesis will be required to determine whether mutations in the SNM1 protein lead to a processing defect in $5.8 \mathrm{~S}$ rRNA similar to that of a mutation in the NME1 gene (Schmitt and Clayton 1993).
The SNM1 gene product has been shown to bind MRP RNA in gel mobility shift and Northwestern experiments. This suggests that the SNM1 protein is not only a component of the RNase MRP RNP complex but that it is specifically bound to the RNA component.

Coimmunoprecipitation experiments have shown that antibodies directed against the SNM1 protein specifically precipitate the MRP RNA. This is a direct demonstration that the SNM1 protein is a component of the RNase MRP ribonucleoprotein complex. However, the RNA component of the RNase P enzyme was not precipitated, indicating that the SNM1 protein is probably not a yeast homolog of the Th/To autoantigen. A yeast temperature-sensitive mutant in rRNA processing (POP1) has been identified recently that exhibits a defect identical to that of a RNase MRP RNA mutant and a RNase P RNA mutant (Lygerou et al. 1994). This gene, $P O P 1$, is most probably a shared protein component between RNase MRP and RNase P and may be the yeast homolog of the mammalian Th/To autoantigen. Enzymatic reconstitution experiments between the SNM1 protein and MRP RNA were unsuccessful (M.E. Schmitt and D.A. Clayton, unpubl.) probably because of the requirement for additional protein subunits (Lygerou et al. 1994).

\section{The SNM1 protein is a new class of} $R N A$-binding protein

Mobility shift experiments, Northwestern analysis, and immunoprecipitation clearly show that the SNM1 protein is an RNA-binding protein. Competition experiments with tRNA and specific immunoprecipitation of MRP RNA suggest that the specificity of the SNM1 protein for MRP RNA is high; however, the exact degree of specificity cannot be determined with the data presented.

The SNM1 protein contains little similarity to any other sequence in the protein data bases. The protein does show three interesting regions, including a potential leucine zipper, a zinc-binding site, and a serine/ lysine rich domain. During purification of the recombinant protein from $E$. coli we found that solubilization of the SNM1 protein from inclusion bodies was dependent on zinc (see Materials and methods), suggesting that zinc is required for the proper folding of the SNM1 protein. Two zinc atoms may be bound to the six cysteine residues in the SNM1 protein in a arrangement similar to the GAL4 protein (Marmorstein et al. 1992). The GAL4 protein forms a binuclear zinc-thiolate cluster with the six sulfur atoms of six cysteine residues. However, the arrangement of the cysteine residues in the $S N M 1$ protein is slightly different than in the GAL4 protein. The SNM1 protein also contains two potential nitrogen-coordinating groups (a histidine and an asparagine) immediately before two of the cysteine residues. These groups could potentially play a role in coordinating the zinc atoms. Future atomic structural analysis is required before any conclusions can be drawn. Nevertheless, this is the first 
identification of an RNA-binding protein with this type of zinc-binding site.

The presence of a potential leucine zipper in the SNM1 protein is also analogous to the GAL4 protein. This domain is responsible for dimerization of the GAL4 zinc clusters and DNA binding (Marmorstein et al. 1992). The presence of the leucine zipper domain implies that the SNM1 protein may be a functional dimer. Finally, the SNM1 protein contains a serine/lysine-rich carboxyl terminus. The function of this domain is unknown; however, a SR domain has been identified in several RNAbinding proteins involved in different aspects of RNA splicing (Birney et al. 1993). This SR domain was shown to be required for certain protein-protein interactions of the Drosophila Transformer 2 gene (Amrein et al. 1994) and for protein-protein interactions between the human splicing factor 2 and protein components of the U1 small nuclear RNP (snRNP) (Kohtz et al. 1994). The SR domain is phosphorylated in some proteins (Woppman et al. 1993; Zahler et al. 1993)

\section{Possible modification of the SNM1 protein}

Analysis of the SNM1 protein in vivo revealed the presence of four antisera-reactive protein species of differing mobilities. We predict that these species are three differently phosphorylated forms and the mature unphosphorylated form of the protein. These species are probably not highly homologous members of the same gene family because cross-hybridization of the SNM1 gene to other regions of the yeast genome was not observed (data not shown). The serine/lysine-rich tail of the SNM1 protein contains several consensus phosphorylation sites, including those for the cAMP-dependent protein kinase. Preliminary results revealed differential accumulation of different modified species depending on whether yeast were in $\log$-phase or in stationary-phase growth (M.E. Schmitt and D.A. Clayton, unpubl.) Phosphorylation might provide a control mechanism for the RNase MRP enzyme by regulating it during periods of high and low ribosome biogenesis. This phosphorylation may be carried out by the cAMP-dependent protein kinase with high activity under nutrient-rich conditions and periods of high ribosome biogenesis, and low activity under nutrient poor conditions and periods of low ribosome biogenesis (Thevelein 1992).

\section{Suppression of the nmel-P6 mutation by the SNM1 gene product}

Because the SNM1 protein is an integral part of the RNase MRP enzyme complex, it must be suppressing the nme1-P6 mutation by compensating for the RNA mutation when overexpressed. The simplest model predicts that the SNM1 protein normally binds the MRP RNA in the region of the nme1-P6 mutation (nucleotide 122). We postulate that in the nme1-P6 mutant this binding is unstable, especially at higher temperatures, and the SNM1 protein is degraded when not assembled with the RNA component. This absence of the SNM1 protein from the RNase MRP complex results in loss of RNase MRP activity and a subsequent failure to process rRNA. When yeast are carrying the SNM1 gene on a high-copy plasmid, expression of the gene increases severalfold and a concomitant increase in SNM1 protein occurs. This increase in the cellular levels of the SNM1 protein is enough to favor binding of the protein to this mutated RNA target, restoring RNase MRP activity and rRNA processing. Further examination of this proteinRNA interaction should help to reveal principal features of RNase MRP structure and function.

\section{Materials and methods \\ Media and E. coli strains}

Yeast media and genetic manipulations have been described (Sherman 1991). S. cerevisiae strains used in this study are listed below. The $E$. coli strain used for cloning, $\mathrm{DH} 5 \alpha$, has the genotype psi80dlacZLM15, endA1, recA1, hsdR17 $\left(\mathrm{r}_{\mathrm{k}}{ }^{-} \mathrm{m}_{\mathrm{k}}{ }^{+}\right)$, supE44, thi-1, $\lambda^{-}$, gyrA96, relA1, $\Delta($ lacZya-argF $) \mathrm{U169}, \mathrm{F}^{-}$.

\section{RNA analysis}

Total yeast RNA was prepared as described previously (Schmitt et al. 1990). Northern analysis was performed as described (Schmitt and Trumpower 1990). Hybridization probes were made using the Prime-It Kit (Stratagene Inc.).

\section{Identification of nme1-P6 suppressors}

The yeast strain MES116 [MATa, lys2-801, his3- $\Delta 200$, leu23,112, ura3-52, trp1- $\Delta 1$, nme1- $\Delta 2$ :TRP1, pMES140 (pRS315:: nme1-P6. LEU2, CEN)] carrying the nme1-P6 mutation (a $\mathrm{G} \rightarrow \mathrm{A}$ transition at position 122 of the NME1 gene; Schmitt and Clayton 1993) was transformed with a yeast URA3, $2 \mu$ genomic library (Carlson and Botstein 1982) and plated onto $\mathrm{Ura}^{-}$media at $24^{\circ} \mathrm{C}$. Ten thousand transformants were replicaplated to SD complete media (Sherman 1991) at $37^{\circ} \mathrm{C}$. Colonies growing at the nonpermissive temperature were picked and retested. Those transformants that continued to grow at $37^{\circ} \mathrm{C}$ on SD complete plates, but failed to grow at $37^{\circ} \mathrm{C}$ on SD complete plates with 5 -fluoro-orotic acid, were classified as plasmid-linked suppressors. Yeast $2 \mu$ plasmids that conferred $37^{\circ} \mathrm{C}$ growth were rescued from yeast into $E$. coli (Sikorski and Boeke 1991) and then retested for suppression in the original nme1-P6 strain.

\section{Gene mapping and complementation analysis}

Four independently isolated clones were found to complement the nme1-P6 mutation at $37^{\circ} \mathrm{C}$. These clones were restriction mapped by standard methods (Sambrook et al. 1989) and found to contain overlapping fragments of the same region of the yeast genome. Using the yeast-ordered genomic library (Riles et al 1993) the S3 clone was mapped to the same cosmid as the SNF1 gene on the right arm of chromosome IV (Celenza and Carlson 1984). Comparison of the restriction maps of our suppressing inserts and the SNF1 genomic region revealed them to be identical. The plasmid pMES171, which contains a 3.2-kb EcoRI fragment in the $2 \mu$ /URA3 vector YEP352 (Hill et al. 1986) encompassing the entire $S N F 1$ gene, was unable to confer any suppression on the nme1-P6 mutation. A 1.0-kb BamHI fragment downstream of the SNF1 gene when inserted into the 
vector YEP352 was found to provide partial suppression of the nme1-P6 mutation. A 1.2-kb PCR fragment extending from the $3^{\prime}$ end of the SNF1 gene was able to provide full suppression at $37^{\circ} \mathrm{C}$ on the nme1-P6 mutation. The PCR oligonucleotides used to generate this fragment are O-snml-1 (5'-AAGCTTTTTCAGCCTACCCATTTT-3') and O-snml-2 (5'-CTGTCAGGCAAGGCGTACATGGCGTG-3'). A series of different fragments was tested in the vector YEP352 (Hill et al. 1986) for suppression of the nme1-P6 mutation and is summarized in Figure $2 \mathrm{~A}$.

The complementing fragment was sequenced on both strands from -380 of the initiator methionine of SNM1 to the $X b a$ I site at +1694 using the Sequenase DNA sequencing kit. The entire sequence has been entered into EMBL, accession number Z37982.

\section{Deletion of SNM1}

The SNM1 gene was deleted as follows. The plasmid pMES192 contains a 1202 -bp fragment (from -380 bp $5^{\prime}$ to 226 bp $3^{\prime}$ ) of the SNM1 gene in the HindIII-PstI sites of pUC19. This plasmid was digested with SpeI and NsiI to remove a 745-bp fragment containing the entire SNM1-coding region, and a 1305-bp NsiI$\mathrm{XbaI}$ fragment containing the entire HIS3 gene was joined to create the plasmid pMES201. The resulting plasmid pMES201 was transformed into the diploid yeast strain MES101 (MATa) MATa his3- $\Delta 200 /$ his3- $\Delta 200$ leu2-3,112/leu2-3,112 ura3-52/ ura3-52 trp1-41/trp1- $\Delta$ l ADE2/ade2-1 LYS2/lys2-801) (Schmitt and Clayton 1993), and integrants were selected on minimal media without histidine (Sherman 1991). Transformants were initially screened for proper homologous integration into the SNM1 locus using PCR and then confirmed by Southern analysis (Schmitt and Clayton 1993). A diploid strain of yeast with one deleted copy of the SNM1 gene was used for further study, MES150 (MATa/MATa his3-4200/his34200 leu2-3,112/leu23,112 ura3-52/ura3-52 trp1- $\Delta 1 /$ trp1- $\Delta$ l ADE2/ade2-1 LYS2/ lys2-801 SNM1/snm1- $\Delta 1::$ HIS3). The MES150 strain was sporylated and tetrads were dissected. Tetrads always gave a 2:0 phenotype, and the two viable spores were always found to be His ${ }^{-}$. The inviable spores were examined under a microscope and were never found to pass the two-cell stage. The plasmid pMES194 (LEU2, CEN, SNM1) or pMES202 (URA3, 2 $\mu, S N M 1$ ) was transformed into the strain MES150, and the resultant strains were sporulated. Tetrads were dissected and $\mathrm{His}^{+}$spores were identified at an expected frequency, although these strains were always $\mathrm{Leu}^{+}$or $\mathrm{Ura}^{+}$, indicating that they maintained the pMES194 or pMES202 plasmids. These plasmids could not be lost from these haploid snm1-deleted cells. The plasmids pMES194 and pMES202 were constructed by cloning the $1.2 \mathrm{~kb}$ HindIII-PstI fragment of pMES192, containing the SNM1 gene, into the HindIII-PstI sites of the vectors pRS315 (Sikorski and Heiter 1989) and YEP352 (Hill et al. 1986), respectively.

\section{Protein expression and purification}

The SNM1 protein was expressed in E. coli and purified as follows. The 742-bp EcoRI-PstI fragment of the SNM1 gene from pMES192 was cloned into the EcoRI and PstI sites of the plasmid pT7-7 (Tabor and Richardson 1992) to create the plasmid pMES203. Utilizing PCR and the oligonucleotides O-snml-3 (5'-AAAACATATGAATAAAGACCAGGCAGAA3') and O-snm1-4 (5'-CTCTGGAATTCAGTGTTGGCAG-3'), a 97-bp fragment encompassing the amino terminus of the SNM1 gene was generated. This fragment was digested with EcoRI and NdeI and cloned into the EcoRI and NdeI sites of the plasmid
pMES203 to construct the plasmid pMES204. The plasmid pMES204 expresses the natural full-length SNM1 protein open reading frame from the T7 RNA polymerase promoter. The fragment generated by PCR was resequenced to ensure the fidelity of the SNM1 gene. The plasmid was transformed into the E. coli strain BL21 (DE3) $F^{-}$, omp T, hsdS ${ }_{B},\left(\mathrm{r}_{\mathrm{b}}{ }^{-}, \mathrm{m}_{\mathrm{b}}{ }^{-}\right.$, an E. coli B strain with a $\lambda$ prophage carrying the T7 RNA polymerase gene).

The SNM1 protein was expressed from the pMES204 plasmid, and inclusion bodies were purified and washed (Sambrook et al. 1989). Inclusion bodies were solubilized in $50 \mathrm{~mm}$ Tris- $\mathrm{HCl}$ at $\mathrm{pH} 8.0,3 \mathrm{M}$ guanidine chloride, and $0.5 \mathrm{~mm} \mathrm{DTT}$ at $24^{\circ} \mathrm{C}$ for 30 min. This mixture was then diluted 25 -fold into $50 \mathrm{mM}$ Tris$\mathrm{HCl}, \mathrm{pH} 8.0,0.5 \mathrm{~mm}$ DTT. When dilution was performed in this buffer without zinc, all of the SNM1 protein precipitated from solution. The precipitate containing the SNM1 protein was cleared from the supernatant by spinning at $15,000 \mathrm{~g}$ for $15 \mathrm{~min}$ and was then resolubilized as described above. This buffer was then diluted 25-fold into $50 \mathrm{~mm}$ Tris- $\mathrm{HCl}, \mathrm{pH}$ 8.0, 0.5 mM DTT, and $10 \mu \mathrm{M} \mathrm{ZnCl}$. When dilution was performed in this buffer with zinc, $\sim 60 \%$ of the $S N M 1$ protein was soluble. The precipitate was removed as described above while the supernatant that contained the bulk of the SNM1 protein was concentrated through a Centriprep-10, made $50 \%$ glycerol and stored at $-20^{\circ} \mathrm{C}$.

\section{Antibody production}

SNM1 protein purified as described above was sent to Josman Laboratories, Napa, CA. A standard polyclonal antibody production protocol was followed in rabbits (Harlow and Lane 1988). Serum was cleared against a whole-cell $E$. coli lysate of BL21 (DE3) that did not harbor an expression plasmid (Harlow and Lane 1988).

\section{Whole-cell yeast protein extraction}

Ten-milliliter cultures of yeast strains were grown to $2 \times 10^{7}$ cells $/ \mathrm{ml}$, and the cells were harvested and transferred to a microcentrifuge tube. The cells were washed once with water and once with buffer A $150 \mathrm{~mm}$ Tris- $\mathrm{HCl}$, pH 8.0, $150 \mathrm{~mm} \mathrm{KCl}, 5 \mathrm{mM}$ EDTA, $1 \mathrm{~mm}$ DTT). The cells were resuspended in $400 \mu \mathrm{l}$ of buffer $\mathrm{A}$ and $200 \mathrm{mg}$ of glass beads was added. The mixture was then vortexed for $15 \mathrm{~min}$ at $4^{\circ} \mathrm{C}$. The samples were then transferred to a microcentrifuge tube and centrifuged at $14,000 \mathrm{~g}$ for $10 \mathrm{~min}$. The supernatant was removed and stored at $-70^{\circ} \mathrm{C}$ until used.

\section{SDS-PAGE and Western analyses}

SDS-PAGE was performed by the method of Laemmli (1970). Western analysis was performed by the method of Ljungdahl et al. (1989). The anti-SNM1-p antibodies were used at 1:1500 dilution for Western analysis.

\section{RNA mobility shift}

The full-length MRP transcript was generated using SP6 RNA polymerase on NcoI-digested pMES206. The pMES206 plasmid was generated by using site-directed mutagenesis to place a SP6 RNA polymerase initiation site at the $5^{\prime}$ end of the NME1 gene in the plasmid pMES140 (Schmitt and Clayton 1993). The oligonucleotide used was OMS-30 (5'-CTCGTTTAAAGTTAACATTTAGGTGACACTATAGAATCCATGACCA-3'). The SP6 transcript has one extra $G$ on the $5^{\prime}$ end and seven fewer nucleotides on the $3^{\prime}$ end when compared to the in vivo RNA. The $3^{\prime}$-terminal eight nucleotides are not required for function 
of the NME1 RNA in vivo (M.E. Schmitt, G.S. Shadel, and D.A. Clayton, unpubl.). The in vitro-transcribed MRP RNA was labeled either internally with $\left[{ }^{32} \mathrm{P}-\alpha\right] \mathrm{UTP}$ or at the $3^{\prime}$ end with $\left[{ }^{32} \mathrm{P}\right] \mathrm{pCp}$ (Chang and Clayton 1989).

Approximately $50,000 \mathrm{cpm}$ of labeled RNA was incubated with purified SNM1 protein for $20 \mathrm{~min}$ in $0.5 \times$ TBE in a 10- $\mu \mathrm{l}$ reaction at $24^{\circ} \mathrm{C}$. Five microliters of $20 \%$ glycerol and $0.5 \mathrm{mg} /$ $\mathrm{ml}$ of bromophenol blue were then added, and the reactions were loaded onto a $4 \%$ acrylamide $(37.5: 1), 0.5 \times$ TBE gel. Complexes were separated at $10 \mathrm{~W}$ constant power for $60 \mathrm{~min}$. Competing $E$. coli tRNA was added prior to the addition of protein. When heparin was used, it was added after the $20 \mathrm{~min}$ incubation and the samples were given an additional $10 \mathrm{~min}$ incubation at room temperature prior to the addition of loading buffer.

\section{Northwestern analysis}

Purified SNM1 protein was separated on a $15 \%$ SDS-PAGE gel and transferred to nitrocellulose. The membrane was blocked for $1 \mathrm{hr}$ (at $24^{\circ} \mathrm{C}$ in PBS, $5 \%$ bovine serum albumin, and $0.1 \%$ Triton X-100 (Sambrook et al. 1989). The membrane was then probed in PBS with $0.1 \%$ Triton X-100,1 $\mu \mathrm{g} / \mathrm{ml}$ of $E$. coli tRNA, and $2 \times 10^{6} \mathrm{cpm}$ of internally ${ }^{32} \mathrm{P}$-labeled MRP RNA at $10^{9} \mathrm{cpm} /$ $\mu \mathrm{g}$ for $30 \mathrm{~min}$ at $24^{\circ} \mathrm{C}$. Concentrations of $E$. coli tRNA of up to $100 \mu \mathrm{g} / \mathrm{ml}$ could be used during the blocking and probing without a reduction in signal. The membrane was then washed $4 \times 10$ min in PBS with $0.1 \%$ Triton X-100 at $24^{\circ} \mathrm{C}$ and exposed to film.

\section{Immunoprecipitation by anti-SNM1-p antibodies}

Fifty microliters of $200 \mathrm{mg} / \mathrm{ml}$ protein A-Sepharose CL4B in buffer $\mathrm{A}$ was incubated with rabbit serum for $1 \mathrm{hr}$ at $4^{\circ} \mathrm{C}$. Five hundred microliters of buffer A was added to the sample, the beads were pelleted by centrifugation for $5 \mathrm{sec}$ in a microcentrifuge, and the supernatant was removed. The pellet was then washed two more times with $500 \mu \mathrm{l}$ of buffer $\mathrm{A}$, and the supernatant was removed. The sample was then brought to $80 \mu \mathrm{l}$ with buffer A, $20 \mu \mathrm{l}$ of a yeast whole-cell protein extract was added, and the reaction was allowed to incubate at $4^{\circ} \mathrm{C}$ for an additional hour. The sample was then centrifuged in a microcentrifuge for $5 \mathrm{sec}$, and the supernatant was removed and saved. The pellet was washed three times with $500 \mu$ l of buffer $A$, and the supernatant was discarded. One hundred microliters of $5 \%$ SDS, $10 \% 2$-mercaptoethanol was added to both of the pellets and the supernatants. The samples were heated to $95^{\circ} \mathrm{C}$ for $5 \mathrm{~min}$, and an equal volume of phenol/chloroform/isoamyl alcohol (25:24:1) was added. The sample was vortexed and allowed to stand for $5 \mathrm{~min}$ at $24^{\circ} \mathrm{C}$. The aqueous phase was then separated by centrifugation, and the RNA was precipitated with the addition of one-tenth volume of $3 \mathrm{M}$ sodium acetate and 2.5 volumes of ethanol. The RNA samples were then subjected to Northern analysis as described previously (Schmitt and Clayton 1993) The NME1 probe and the SCR1 probe were as described previously (Schmitt and Clayton 1993). The RNase P probe was a randomly labeled 450-bp PCR fragment generated using the oligonucleotides OMES-P1 (5'-ACTCTGGGAGCTGCGATTGGC-3') and OMES-P2 (5'-CTTTCTGTATCGCAAATAAGTG-3') on yeast genomic DNA.

\section{Acknowledgments}

We thank J.D. Garman, D.Y. Lee, B.A. Morisseau, and G.S. Shadel for comments on the manuscript and for helpful discussions during this investigation. This work was supported by grant GM33088-24 from the National Institute of General Med- ical Sciences and a Damon Runyon-Walter Winchell Cancer Research Fund Fellowship (DRG-1 108) to M.E.S. We are grateful to D. Botstein for plasmids, yeast strains, and the yeast genomic library.

The publication costs of this article were defrayed in part by payment of page charges. This article must therefore be hereby marked "advertisement" in accordance with 18 USC section 1734 solely to indicate this fact.

\section{References}

Amrein, H., M.L. Hedley, and T. Maniatis. 1994. The role of specific protein-RNA and protein-protein interactions in positive and negative control of pre-mRNA splicing by Transformer 2. Cell 76: 735-746.

Bartkiewicz, M., H. Gold, and S. Altman. 1989. Identification and characterization of an RNA molecule that copurifies with RNase P activity from HeLa cells. Genes \& Dev. 3: 488-499.

Bennett, J.L., S. Jeong-Yu, and D.A. Clayton. 1992. Characterization of Xenopus laevis RNase MRP: Isolation of the RNA component and its expression during development. J. Biol. Chem. 267: 21765-21772.

Birney, E., S. Kumar, and A. R. Krainer. 1993. Analysis of the RNA-recognition motif and RS and RGG domains: Conservation in metazoan pre-mRNA splicing factors. Nucleic Acids Res. 21: 5803-5816.

Busch, S.J. and P. Sassone-Corsi. 1990. Dimers, leucine zippers and DNA-binding domains. Trends Genet. 6: 36-40.

Carlson, M. and D. Botstein. 1982. Two differentially regulated mRNAs with different $5^{\prime}$ ends encode secreted and intracellular forms of yeast invertase. Cell 28: 145-154.

Celenza, J.L. and M. Carlson. 1984. Cloning and genetic mapping of SNF1, a gene required for expression of glucose-repressible genes in Saccharomyces cerevisiae. Mol. Cell. Biol. 4: $49-53$.

1986. A yeast gene that is essential for release from glucose repression encodes a protein kinase. Science 233: 1175-1180.

Chang, D.D. and D.A. Clayton. 1987a. A novel endoribonuclease cleaves at a priming site of mouse mitochondrial DNA replication. EMBO I. 6: 409-417.

- $1987 \mathrm{~b}$. A mammalian mitochondrial RNA processing activity contains nucleus-encoded RNA. Science 235: 11781184.

- 1989. Mouse RNAase MRP RNA is encoded by a nuclear gene and contains a decamer sequence complementary to the conserved region of mitochondrial RNA substrate. Cell 56: 131-139.

Chu, S., R.H. Archer, J.M. Zengel, and L. Lindahl. 1994. The RNA of RNase MRP is required for normal processing of ribosomal RNA. Proc. Natl. Acad. Sci. 91: 659-663.

Dairaghi, D.J. and D.A. Clayton. 1993. Bovine RNase MRP cleaves the divergent bovine mitochondrial RNA sequence at the displacement-loop region. $J$. Mol. Evol. 37: 338-346.

Felici, F., G. Cesareni, and J.M.X. Hughes. 1989. The most abundant small cytoplasmic RNA of Saccharomyces cerevisae has an important function required for normal cell growth. Mol. Cell. Biol. 9: 3260-3268.

Forster, A.C. and S. Altman. 1990. Similar cage-shaped structure for the RNA components of all ribonuclease $\mathrm{P}$ and ribonuclease MRP enzymes. Cell 62: 407-409.

Fournier, M.J. and E.S. Maxwell. 1993. The nucleolar snRNAs: Catching up with the spliceosomal snRNAs. Trends Biochem. Sci. 18: 131-135. 
Gold, H.A., J.N. Topper, D.A. Clayton, and J. Craft. 1989. The RNA processing enzyme RNase MRP is identical to the Th RNP and related to RNase P. Science 245: 1377-1380.

Greider, C.W. and E.H. Blackburn. 1989. A telomeric sequence in the RNA of Tetrahymena telomerase required for telomere repeat synthesis. Nature 337: 331-337.

Harlow, E. and D. Lane. 1988. Antibodies: A laboratory manual, Cold Spring Harbor Laboratory, Cold Spring Harbor, New York.

Henry, Y., H. Wood, J.P. Morrissey, E. Petfalski, S. Kearsey, and D. Tollervey. 1994. The $5^{\prime}$ end of yeast $5.8 \mathrm{~S}$ rRNA is generated by exonucleases from an upstream cleavage site. $E M B O$ I. 13: 2452-2463.

Hill, J.H., A.M. Meyers, T.J. Koerner, and A. Tzagoloff. 1986. Yeast/E. coli shuttle vectors with multiple unique restriction sites. Yeast 2: 163-167.

Karwan, R., J.L. Bennett, and D.A. Clayton. 1991. Nuclear RNase MRP processes RNA at multiple discrete sites: Interaction with an upstream $G$ box is required for subsequent downstream cleavages. Genes et) Dev. 5: 1264-1276.

Kiss, T. and W. Filipowicz. 1992. Evidence against a mitochondrial location of the 7-2/MRP RNA in mammalian cells. Cell 70: 11-16.

Kiss, T., C. Marshallsay, and W. Filipowicz. 1992. 7-2/MRP RNAs in plant and mammalian cells: Association with higher order structures in the nucleolus. EMBO I. 10: 37373746.

Kohtz, J. D., S.F. Jamison, C.L. Will, P. Zuo, R. Luhrmann, M.A. Garcia-Blanco, and J.L. Manley. 1994. Protein-protein interactions and 5 '-splice-site recognition in mammalian mRNA precursors. Nature 368: 119-124.

Laemmli, U.K. 1970. Cleavage of structural proteins during the assembly of the head of bacteriophage T4. Nature 227: 680685.

Lee, J., C.E. Rohlman, L.A. Molony, and D.R. Engelke. 1991. Characterization of $R P R 1$, an essential gene encoding the RNA component of Saccharomyces cerevisiae nuclear RNase P. Mol. Cell. Biol. 11: 721-730.

Li, K., C.S. Smagula, W.J. Parsons, J.A. Richardson, M. Gonzalez, H.K. Hagler, and R.S. Williams. 1994. Subcellular partitioning of MRP RNA assessed by utrastructural and biochemical analysis. I. Cell Biol. 124: 871-882.

Lindahl, L., R.H. Archer, and J.M. Zengel. 1992. A new rRNA processing mutant of Saccharomyces cerevisiae. Nucleic Acids Res. 20: 295-301.

Ljungdahl, P.O., J.D. Beckmann, and B.L. Trumpower. 1989. Mutational analysis of the mitochondrial Reiske iron-sulfur protein of Saccharomyces cerevisiae II: Biochemical characterization of temperature-sensitive rip $1^{-}$mutations. J. Biol. Chem. 264: 3723-3731.

Lygerou, Z., P. Mitchell, E. Petfalski, B. Séraphin, and D. Tollervey. 1994. The POP1 gene encodes a protein component common to the RNase MRP and RNase P ribonucleoproteins. Genes \& Dev. 8: 1423-1433.

Marmorstein, R., M. Carey, M. Ptashne, and S.C. Harrison. 1992. DNA recognition by GAL4: Structure of a proteinDNA complex. Nature 356: 408-414.

Mattaj, I.W., D. Tollervey, and B. Séraphin. 1993. Small nuclear RNAs in messenger RNA and ribosomal RNA processing. FASEB I. 7: 47-53.

Noller, H.F. and C.R. Woese. 1981. Secondary structure of $16 \mathrm{~S}$ ribosomal RNA. Science 212: 403-411.

O'Halloran, T. V. 1993. Transition metals in control of gene expression. Science 261: 715-725.

Reimer, G., I. Raska, V. Scheer, and E.M. Tan. 1988. Immunolocalization of 7-2 ribonucleoprotein in the granular compo- nent of the nucleolus. Exp. Cell Res. 176: 117-128.

Riles, L., J.E. Dutchik, A. Baktha, B.K. McCauley, E.C. Thayer, M. P. Leckie, V. V. Braden, J.E. Depke, and M.V. Olson. 1993. Physical maps of the six smallest chromosomes of Saccharomyces cerevisiae at a resolution of 2.6 kilobase pairs. Genetics 134: 81-150.

Rine, J. 1991. Gene overexpression studies of Saccharomyces cerevisae. Methods Enzymol. 194: 239-251.

Rossmanith, W. and R. Karwan. 1993. Definition of the Th/To ribonucleoprotein by RNase P and RNase MRP. Mol. Biol. Reports 18: 29-35.

Rothstein, R.J. 1991. Targeting, disruption, replacement, and allele rescue: Integrative DNA transformation in yeast. Methods Enzymol. 194: 281-301.

Rubin, G.M. 1974. Three forms of the 5.8S ribosomal RNA species in Saccharomyces cerevisiae. Eur. J. Biochem. 41: 197202.

Sambrook, J., E.F. Fritsch, and T. Maniatis. 1989. Molecular cloning: A laboratory manual, Cold Spring Harbor Laboratory Press, Cold Spring Harbor, New York.

Schmitt, M.E. and D.A. Clayton. 1992. Yeast site-specific ribonucleoprotein endoribonuclease MRP contains an RNA component homologous to mammalian RNase MRP RNA and essential for cell viability. Genes \& Dev. 6: 1975-1985.

- 1993. Nuclear RNase MRP is required for correct processing of pre-5.8S rRNA in Saccharomyces cerevisiae. Mol. Cell. Biol. 13: 7935-7941.

Schmitt, M.E. and B.L. Trumpower. 1990. Subunit 6 regulates half-of-the-sites reactivity of the cytochrome $b_{1}$ complex in Saccharomyces cerevisiae. J. Biol. Chem. 265: 17005-17011.

Schmitt, M.E., T.A. Brown, and B.L. Trumpower. 1990. A rapid, improved method for isolation of RNA from Saccharomyces cerevisiae. Nucleic Acids Res. 18: 3091-3092.

Schmitt, M.E., J.L. Bennett. D.J. Dairaghi, and D.A. Clayton. 1993. Secondary structure of RNase MRP RNA as predicted by phylogenetic comparison. FASEB I. 7: 208-213.

Sherman, F. 1991. Getting started with yeast. Methods Enzymol. 194: 3-21.

Shuai, K. and J.R. Warner. 1991. A temperature sensitive mutant of Saccharomyces cerevisiae defective in pre-rRNA processing. Nucl. Acids Res. 19: 5059-5064.

Sikorski, R.S. and J.D. Boeke. 1991. In vitro mutagenesis and plasmid shuffling: From cloned gene to mutant yeast. Methods Enzymol. 194: 302-318.

Sikorski, R.S. and P. Hieter. 1989. A system of shuttle vectors and yeast host strains designed for efficient manipulation of DNA in Saccharomyces cerevisiae. Genetics 122: 19-27.

Stohl L.L. and D.A. Clayton. 1992. Saccharomyces cerevisiae contains an RNase MRP that cleaves at a conserved mitochondrial RNA sequence implicated in replication priming. Mol. Cell. Biol. 12: 2561-2569.

Tabor, S. and C.C. Richardson. 1992. A bacteriophage T7 RNA polymerase/promoter system for controlled exclusive expression of specific genes. BioTechnology 24: 280-284.

Thevelein, J.M. 1992. The RAS-adenylate cyclase pathway and cell cycle control in Saccharomyces cerevisiae. J. Microbiol. Antonie Leeuwenhoek 62: 109-130.

Tollervey, D. 1987. A yeast small nuclear RNA is required for normal processing of pre-ribosomal RNA. EMBO J. 6: 41694175.

Topper, J.N. and D.A. Clayton. 1990a. Characterization of human MRP/Th RNA and its nuclear gene: Full length MRP/ Th RNA is an active endoribonuclease when assembled as an RNP. Nucleic Acids Res. 18: 793-799.

- 1990b. Secondary structure of the RNA component of a nuclear/mitochondrial ribonucleoprotein. J. Biol. Chem. 
265: 13254-13262.

Topper, J.N., J.L. Bennett, and D.A. Clayton. 1992. A role for RNAase MRP in mitochondrial RNA processing. Cell 70: 16-20.

Wong, T.W. and D.A. Clayton. 1986. DNA primase of human mitochondria is associated with structural RNA that is essential for enzymatic activity. Cell 45: 817-825.

Woolford Jr., J.L. 1991. The structure and biogenesis of yeast ribosomes. Adv. Genet. 29: 63-118.

Woppmann, A., C.L. Will, U. Kornstädt, P. Zuo, J.L. Manley, and R. Lührmann. 1993. Identification of an snRNP-associated kinase activity that phosphorylates arginine/serine rich domains typical of splicing factors. Nucleic Acids Res. 21: 2815-2822.

Yuan, Y., E. Tan, and R. Reddy. 1991. The 40-kilodalton To autoantigen associates with nucleotides 21 to 64 of human mitochondrial RNA processing/7-2 RNA in vitro. Mol. Cell. Biol. 11: 5266-5274.

Zahler, A.M., K.M. Neugebauer, J.A. Stolk, and M.B. Roth. 1993. Human SR proteins and isolation of a cDNA encoding SRp75. Mol. Cell. Biol. 13: 4023-4028. 


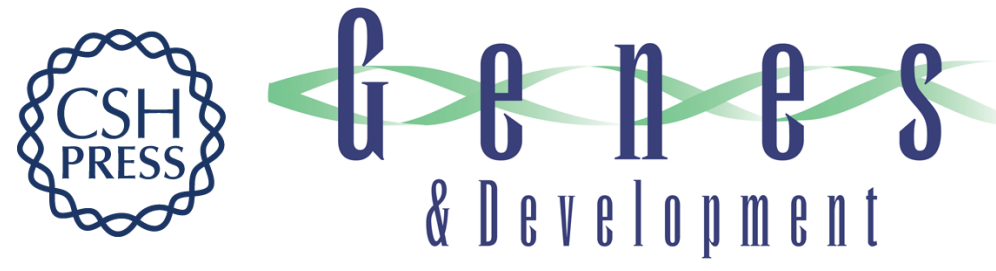

\section{Characterization of a unique protein component of yeast RNase MRP: an RNA-binding protein with a zinc-cluster domain.}

M E Schmitt and D A Clayton

Genes Dev. 1994, 8:

Access the most recent version at doi:10.1101/gad.8.21.2617

References This article cites 61 articles, 23 of which can be accessed free at:

http://genesdev.cshlp.org/content/8/21/2617.full.html\#ref-list-1

License

Email Alerting

Service

Receive free email alerts when new articles cite this article - sign up in the box at the top right corner of the article or click here.

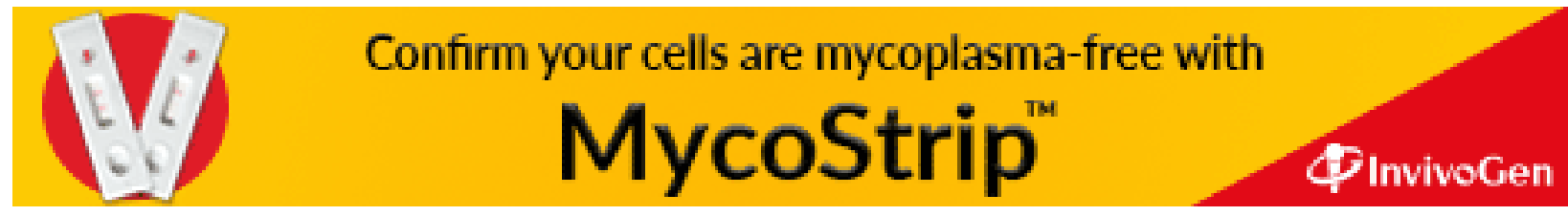

